\title{
A qualitative study on the values of moral eco- pedagogy: A case study of a Romanian school
}

Radu Simion, Alina S. Rusu 


\title{
A qualitative study on the values of moral eco-pedagogy: A case study of a Romanian school
}

\author{
Radu Simion ${ }^{a^{*}}$, Alina S. Rusu ${ }^{\mathrm{b}}$ \\ ${ }^{a}$ Faculty of History and Philosophy, Babes-Bolyai University, 1 Mihail Kogalniceanu Street, 400084, Cluj-Napoca, Romania \\ ${ }^{b}$ Faculty of Psychology and Educational Sciences, Babes-Bolyai University, 7 Sindicatelor Street, 400029, Cluj-Napoca, Romania \\ *Corresponding author: radusimiondan@yahoo.com
}

\section{Abstract}

\section{Keywords:}

experiential education; environment;

civic virtues;

humane education
The aim of this paper is to present a qualitative study using a focus-group method applied to a group of educators in a private nature-oriented school in Romania (Green School Romania), with the purpose of identifying ecological friendly behavioral models, values and virtues shown by children in relation to the natural environment. The importance of this interdisciplinary study is related to the pedagogical philosophy of the above mentioned Romanian school, which is experiential environment-oriented education, a holistic approach to environmental ethics, considered as a moral education for sustainability, trust and care for life and nature.

\section{Zusammenfasung}

\section{Schlüsselworte:} Erfahrungsbildung; Umgebung; bürgerliche Tugenden; humane Bildung
Ziel dieses Artikels ist es, eine qualitative Studie unter Verwendung einer Fokusgruppe unter den Pädagogen einer Privatschule in Rumänien (Green School Romania) vorzustellen, um die Modelle, Tugenden und Schutzwerte von zu identifizieren die Umwelt bei Kindern, die einer natürlichen Umgebung ausgesetzt sind. Die Bedeutung dieser interdisziplinären Studie hängt mit der oben erwähnten Bildungsphilosophie der rumänischen Schule zusammen: eine auf die Umwelt ausgerichtete Erfahrungsbildung, ein ganzheitlicher Ansatz zur Umweltethik als moralische Erziehung zur Nachhaltigkeit, Leben und Natur vertrauen und schützen.

\section{Introduction}

Learning can be defined as a process which brings together personal and interaction experiences related to the environment, all these having the potential to influence, modify and structure knowledge, skills, attitudes, behaviors and values of the learners. Experiential learning is situated on the confluence of different theories from educational psychology and pedagogy, putting together elements specific to behaviorism theory, cognitive psychology, but also from social constructivism and situated learning. According to Chapman, McPhee and Proudman (1995), experiential education is characterized by an equilibrium between experiential activities and the reflection on these experiences, that is taking place in an emotional safe space, where the facilitator (educator) is capable of empathy, without unjustified fears and blaming. This way, the facilitator creates a space where the learner can successfully initiate and participate in activities that fit his needs and interests, discovering the internal motivation for investing time and effort for the success of his/her actions.

In the process of experiential education, the knowledge can be seen as a process rather than a product, because the products of cognitive biases are continuously redefined depending on the nature and the quality of experience itself (Moon J.A., 2004; Wurdinger, 2005). The learning process is more than a banking model of storage information, as Paulo Freire claimed (2005), where he considered that "Education thus becomes an act of depositing, in which the students are the depositories and the teacher is the depositor...Knowledge emerges only through invention and re-invention, through the restless, impatient, continuing, hopeful inquiry human beings pursue in the world, with the world, and with each other."

\section{Theoretical foundation}


Moral education is a vast concept illustrating a phenomenon consisting of all the methods by which individuals form their moral conscience and behaviour. According to Constantin Cucoș (2014), a person is morally educated "...when the person makes a transition from the stage of moral heteronomy, that is to follow the rules promulgated by others, to the stage of moral autonomy, to the self-imposition of internal rules or values." In other words, the process of moral education aims to develop the capacity for free exercise, without constraints and pressures, the capacity for moral selfregulation, the formation of a moral conscience being achieved by focusing on the development of representations and moral notions, conceptions, beliefs and feelings. By the action on the character, the moral will and the moral skills, the moral conduct is formed. In relation to environmental ethics, experiential education may be able to achieve, through a wide range of pedagogical methods and practices, the development of ecological moral awareness and moral conduct in relation to other individuals and the surrounding environment.

The methodological background that facilitates the depiction of moral attitudes and values in relation to the environment is a vast one, encompassing storytelling, role-playing, art in nature, debate, involvement in environmental actions, observing natural phenomena, etc. What is important to remember is that, in the case of experiential education in nature, participants to natureoriented educational programs and/or activities learn from nature, about nature and for nature how to reaction and express attitudes, values and aspirations to responsibly take into account the state of the natural environment. Environmental education therefore seeks to understand the dynamics of the environment in order to protect it, proposing to make individuals aware of environmental problems, developing their skills and values to adequately respond to the challenges raised by local, national and international environmental crises. In order to adequately respond to environmental problems, individuals need to be educated, supported and encouraged to approach the environment in all its dimensions (natural, aesthetic, recreational, scientific, technological, social, cultural, economic), while promoting the need for social cooperation to prevent and solve identified ecological problems (Simion, 2019).

\section{Research methodology}


consider that the children face exciting and stimulant emotional, physical and cognitive experiences during the educational activities from Green School Romania?") and Question nr. 4 ("Do you consider that, during the educational activities in Green School Romania, the children consider the natural environment as being a space where they can successfully organize and handle their emotions?") are related to the values of fascination, wonder and awe in nature.

Question nr. 5 ("Do you consider that during the educational activities from Green School Romania the children initiate, with a positive and proactive attitude, actions that can contribute to the conservation and preservation of the natural environment?") and the question nr. 6 ("Do you consider that, during the activities from GSR, the children face and observe problems or problematic situations which potentially affect biodiversity, having then the will of showing the others how they can contribute with possible solutions to face the problems?") are related to the civic responsibility and engagement to both anthropic and biotic communities.

Question nr. 7 ("Do you consider that during the activities from GSR, the experiences from nature help children to create original artistic artefacts and products, responsibly using the resources they have?") and the question nr. 8 ("Do you consider that during the educational activities from GSR the children develop their autonomy in making some decisions concerning anthropic community, but also taking care of the natural environment and moral patients that populate the natural environment?") are related to the educators' perceptions about the level of autonomy of the children, related to creativity, originality and authenticity, patience and appreciation for their attitude and others work in the field of artistic language.

Question nr. 9 ("Do you consider that the educational activities the children are taking part of in GSR support them to identify and to differentiate between different types of interpersonal communication skills, and also to encourage them to use non-violent communication strategies to solve their conflicts?"), question nr. 10 ("Do you consider that the activities from GSR encourage the children to integrate their own emotions into an emotional logic structure?") and the question nr. 11 ("Do you consider that, having direct contact with the environment, the children from GSR manifest a relational harmony with their own self, showing a visible state of satisfaction, on which they communicate in a verbal and nonverbal way?") are related to personal, social and ecological values that are common in a relationship with empathy are relational harmony with the own self, and the others (moral agents and patients).

\section{Results}

The content analysis of the answers from the questionnaires allowed the identification of four specific categories of topics and subjects:

- Category nr. 1: Topics concerning the impact of early-childhood contact with the environment on social, psychological and emotional development of the educators.

- Category $n r$. 2: Topics about how the children from GRS experienced fascination, wonder and admiration towards nature.

- Category nr. 3: Topics concerning the development of civic responsibility and commitment toward anthropic and biotic communities.

- Category nr. 4: Topics related to the development of creativity, originality and authenticity by interaction with the natural environment.

The first category was related to elements concerning the impact of early-childhood contact with nature on emotional and psycho-social development levels of the educators. It has been noted that the psycho-social development of the educators was expected to be reflected in their answers taking into considerations the early experience they had in nature. Elements like wonder and awe, peace and a sense of relief have been mentioned as beneficial. These elements are vital for a healthy emotional development, been considered as elements which fight against alienation, feed emotional resilience and abilities to explore with trust, the world within. The interaction with the environment stared from early age challenged the educators to discover in nature a space of solitude, fantasy, awe and a higher sense of integration and unity, all contributing to the feeling of being accepted in their own world, together with natural elements surrounding him.

Related to fascination, awe and admiration towards nature topic, the educators considered that first, children need to understand the unicity, beauty and the 
mechanisms of life in nature, to be able to nurture feelings of admiration. As key elements in developing a committed ecological consciousness, balance, harmony and interconnectivity were by far the most valuable. Children manifest curiosity, openness for exploring the surroundings, enthusiasm, love and care for all the entities and elements of life that are present in nature. Furthermore, they experience a feeling of bonding by finding elements in their own habitat which makes possible the connection with their own self and with the others. These results are supported by an analysis done on a three-hundred autobiographies of famous writers, in which Edith Cobb (1959) observes that nature was the source of the creation processes initiated by those, claiming that: ,...these writers say they return in memory in order to renew the power and impulse to create at its very source, a source which they describe as the experience of emerging not only into the light of consciousness but into a living sense of dynamic relationship with the outer world. In these memories the child appears to experience both a sense of discontinuity, an awareness of his own unique separateness and identity, and also a continuity, a renewal of relationship with nature as process."

Taking into consideration the analysis of the answers to Questions 3 and 4, nature becomes a space of initiation, in which expressing enthusiasm and wonder become signs of a courageous adventure in a world of learning by play. Having a strong physiological meaning, the way children react to those experiences transform the process of gaining knowledge into a significant learning process, a type of process which connects all sides of human experience. This openness towards experience allows children to access the world by using their senses to gain trust in their capacity to explore and learn, heading towards a state of safety when in nature.

\section{Considering the topic concerning civic responsibility} and commitment toward anthropic and biotic communities, educators have noticed a clear tendency to see them as being part of the daily routine of children from Green School Romania. Children approach problems and difficult situations they face in nature from a systemic perspective, taking into consideration the connections between biotic and anthropic elements, as well as their holistic impact. In the same time, by caring and cleaning outdoor spaces, children develop attitudes like the will to be involved, courage, to care, the feeling of being useful, availability and good will. These virtues can also be named "being rightly oriented towards nature", as Rosalind Hursthouse states (2007).

The above mentioned virtue has been explained by Hursthouse (2007) in Environmental Virtue Ethics, a paper in which she strongly believes that this "... a radical change in one's emotions and perceptions, one's whole way of perceiving and responding to the world, of one's reasons for action and thereby actions." The virtue of being rightly oriented towards nature includes “... wondering at, looking hard at, finding out more about, rejoicing in, understanding why other people spend their whole lives studying, being anxious to preserve, not dismissing or ignoring or destroying or forgetting or assuming one can always put a price on ... everything in the natural world."

In addition, the education for civic responsibility and involvement targets the examination of main environmental threats from a community approach, regional and international, so that children can have a general holistic picture on the effects of the ecological crisis on environmental areas. By being involved in activities of recognizing the ecological threats (like Fridays for Future, an event mentioned by one of the educators as being popular among children in school) the children are empowered to take a stand and to be visible in their group, in the same time promoting the necessity of local and national cooperation to prevent and find solutions to the problems these individual identify.

Related to the topic on developing creativity, originality and authenticity by interacting with nature, the educators' answers to Questions 7 and 8, it has been observed a trend in associating this nature-oriented pedagogic model with the capacity of facilitating the access towards originality and multiple intelligence children poses. In the same time, with the support of the educators, the children are encouraged to be autonomous in taking decisions, always having in their mind how their activities can impact the surroundings. By self-directed experiential learning model, children gain skills that allow them to explore, to test and to express themselves as part of a joyful and flexible discovering process.

Experiential learning in nature initiates activities that are meant to stimulate the sensorial development, to be able to respond to life in general in a creative way. Through art in nature activities, children can express their thoughts, emotions and feelings, using a large variety of 
techniques and resources to have an enthusiastic approach to their interests and needs.

On the topic concerning empathy and relational harmony, experiential outdoor education together with non-violent strategies of communication is capable to lead to positive outcomes in regards of involving children in meaningful relationships with the world, having the trust to reveal themselves and being capable to easily understand the dynamic of the environment, with a greater availability towards helping, involving and caring. Supporting children to express themselves using verbal, non-verbal and paraverbal communication, the non-violent methods lead to a healthier beneficial peaceful relationships. In this qualitative investigation, the educators noticed that the kids give value to the large range of experiences in which they are involved daily, by being drawn to it, developing the ability to manage the conflicts using reasonable compromises. Nevertheless, the overall perceptions of the investigated educators are that nature-oriented programs create healthy emotional charged exchanges out of which the children can autonomously extract the needed socio-emotional resources, accepting the necessity of a mutual codependency between humans and natural environment.

\section{Discussions}

Taking into consideration the results, we can observe the beneficial role of the experiences educators had in nature, starting in childhood, which open a unique and transformative perspective over the human being, who is able to create, in the present moment, a patient and demanding self. It has also been noted that childhood adventures in nature had a healthy impact for educators, by being able to develop a realist sense of flexibility towards life, by being raised in the spirit of selfacceptance, self-love and being able to understand and feel the rhythm of nature.

Analysing the answers, it has been noticed a positive perception over the role of experiential education on the development of character traits. The feeling of being drawn to nature, experiencing curiosity, wonder and courage represent ways of developing a higher sense of trust in their own body capacities. Furthermore, in the process of bonding with your own self, Carl Rogers (1961) states that the experiences in which the body exposes freely to move, without any pressure and fear pose as authentic ways of development, which strengths the peaceful bond between the man himself and the environment which he is interconnected with. This does not mean that the individuals will be free of experiencing obstacles and difficulties, however they will be able to discover, express and handle emotional reactions, with a tendency towards openness on their own experiences, being ,able to permit his total organism, his conscious thought participating, to consider, weight and balance each stimulus, need, and demand, and its relative weight and intensity." (Rogers, 1961).

Nature-based education is a milestone in gaining knowledge about ecosystems and the relations established inside the biological niches, by developing abilities and feelings which can facilitate the access to identify, recognize, plan and solve previously identified ecological threats. For this type of education to have these positive benefits the educators mentioned, it is necessary that this approach to have a clear overview of the environment- as natural habitat, but also as social, moral, cultural, scientific, aesthetic and historical one.

The lack of critics has an important role in developing self-confidence and autonomy, which creates a safe space where originality is encouraged and the learning outcomes are evaluated individually, by taking into consideration the dominant type of intelligence (Gardner, 2011). The children are encouraged to identify their mistakes as part of the learning process, allowing them to discover the challenges without punitive actions. These challenges can contribute on developing the capacity of freely choosing the objectives to which would like to achieve, objectives with a deep personal meaning. During the learning process, children learn from the consequences, using their own process of reflection and, with the support of their educator, are encouraged to find solutions and to enjoy the benefits of the outcome. Hence, the learning process changes and shapes the connections the individual has with himself and with others in a real, organic, meaningful and joyful relationship.

\section{Conclusions}

The purpose of this qualitative study was to collect data concerning the subjective perceptions of the educators whose pedagogical philosophy is experiential outdoor education using non-violent communication strategies, by focusing on developing attitudes and strong moral values in relationship with nature and all the entities from the anthropic community. The aim of this study was 
to create a better picture of how children gain and make use of these values in their learning process, with a desire of highlighting their behavioral habits when included in nature-oriented activities.

As a conclusion, a large number of particular behaviors were revealed in the categories and topics identified by the content analysis of the answers offered by the educators, such as: compassion for animal suffering, the will to preserve, the availability of being present when needed, sensibility in regards of the transitional character of the environment, virtues as curiosity to discover new meanings, to be alert, work as a social virtues, civic responsibility, active listening and simplicity (with a minimum use of money, time and other resources).

\section{Authors note:}

Radu Simion (philosopher and trainer) is currently an Associate Professor at Faculty of Psychology and Educational Sciences, Babes-Bolyai University, ClujNapoca, member of the Center for Applied Philosophy at Babes-Bolyai University, Socio-Educational Animator at Green School Romania. His professional and research interests are: environmental ethics, code of ethics, managerial and public institutions ethics, applied ethics in psychology, ethics of geoengineering, nature-based education.

Alina S. Rusu (biologist and psychologist) is currently an Associate Professor in the Department of Special Education, School of Psychology and Educational Sciences, Babes-Bolyai University, Cluj-Napoca, Romania and member of the Doctoral School "Education, Reflection, Development" (domain: Psychology). Her professional and research interests are: humane education, interdisciplinary curriculum development, applied values of human-animal interactions and the multidimensional study of community-oriented volunteering. She teaches courses in animal psychology, psychobiology of human sexuality, and positive psychology applied to inclusive institutions.
Although performed on a small sample of participants, this research has the potential to contribute to a better understanding of specific topics need to be implemented in environmental ethics and experiential outdoor education studies. Environmental education can be seen as a complex structure which gathers human society and biodiversity as well can be seen in a new light of care, beauty, a balance between human and nature needs. The aspects highlighted in this research can function as a leading point to identifying new research grounds to overcome the ecological threats that nowadays affect the society, regardless of the geographical, social and cultural roots.

\section{References}

Chapman, S., McPhee, P., \& Proudman, B. (1995). What is Experiential Education? In Warren, K. (Ed.), The Theory of Experiential Education (pp. 235-248). Dubuque: Kendall/Hunt Publishing Company.

Cobb, E. (1959). The Ecology of Imagination in Childhood, Daedalus 88: 538-39.

Cucoș, C. (2014). Pedagogy. 3rd Edition. Iași: Polirom.

Freire, P. (2005). Pedagogy of the Oppressed. New York: The Continuum International Publishing Group.

Gardner, H. (2011) Frames of Mind. The Theory of Multiple Intelligences. New York: Basic Books.

Hursthouse, R. (2007) Environmental Virtue Ethics. In Walker R.L. \& Ivanhoe P.J, Working Virtue: Virtue Ethics and Contemporary Moral Problems 155-171, Oxford: Clarendon Press.

Krueger, R. \& Casey M.A. (2009). Focus Groups: a practical guide for applied research. 4th Edition, California: Sage Publications.

Moon, J.A. (2004). A Handbook of Reflective and Experiential Learning: Theory and Practice. New York: Routledge Falmer. Rogers, C. (1961). On becoming a person. Boston: Houghton Mifflin Company.

Wurdinger, S.D. (2005). Using Experiential Learning in the Classroom. Lanham: Scarecrow Education. 